\title{
Community Research
}

\section{The burden of ocular diseases in an underdeveloped village in Southwest Sumba, Eastern Indonesia, 2016}

\author{
Ratna Sitompul, ${ }^{1}$ Yeni D. Lestari, ${ }^{1}$ Simon Siregar, ${ }^{1}$ Asti Ayudianingrum, ${ }^{1}$ Isfiyanto, ${ }^{1}$ Gladys \\ Kusumowidagdo, ${ }^{2}$ Della P. Sari, ${ }^{2}$ Eiko B. Matiur, ${ }^{2}$ Saleha Sungkar ${ }^{3}$ \\ ${ }^{1}$ Department of Ophthalmology, Faculty of Medicine, Universitas Indonesia, Cipto Mangunkusumo Hospital, Jakarta, Indonesia \\ ${ }^{2}$ Faculty of Medicine, Universitas Indonesia, Jakarta, Indonesia \\ ${ }^{3}$ Department of Parasitology, Faculty of Medicine, Universitas Indonesia, Jakarta, Indonesia
}

\section{ABSTRAK}

Latar belakang: Angka prevalensi penyakit mata di suatu daerah penting dalam menentukan rencana program saran kesehatan mata. Tujuan penelitian ini adalah mendeskripsikan beban penyakit mata sebagai langkah awal dalam meningkatkan pelayanan kesehatan mata di daerah yang kurang berkembang di Indonesia.

Metode: Sebuah studi potong lintang dilakukan pada warga Desa Perobatang, Sumba Barat Daya (SBD) pada Juli 2016. Pemeriksaan mata dilakukan oleh dokter spesialis mata dan pengukuran tajam penglihatan oleh optometris. Partisipan diberikan pengobatan sesuai dengan diagnosis. Bagi yang membutuhkan, diberikan tindakan operasi dua bulan setelah pemeriksaan.

Hasil: Setelah dilakukan pemeriksaan mata terhadap 667 dari total 1.469 penduduk, kelainan mata yang paling sering ditemui adalah presbiopia (30,8\%), katarak $(12,8 \%)$, kelainan refraksi (11,3\%), dan pterigium (10,7\%). Proporsi miopia sebanyak 5,9\%, hiperopia sebanyak 5\%, dan astigmatisme sebanyak 2,2\%. Proporsi kebutaan ditemukan sebanyak 10\%. Katarak menyebabkan kebutaan pada 44 partisipan. Penyebab kebutaan lain yang ditemukan adalah age-related macular degeneration, retinopati, atrofi optik, glaukoma, retinal detachment, dan trauma.

Kesimpulan: Beban penyakit mata di Desa Perobatang, SBD, Indonesia Timur termasuk dalam kategori tinggi. Hasil ini menekankan pentingnya tindakan yang menyangkut kesehatan mata masyarakat dari pemerintah lokal dan lembaga swadaya masyarakat untuk meningkatkan pelayanan kesehatan mata di $S B D$.

ABSTRACT

Background: Prevalence estimates of ocular diseases in a given district are important to plan the programs of eye care services. This study aimed to describe the burden of ocular diseases as an initial step in improving eye care services in underdeveloped areas in Indonesia.

Methods: A cross-sectional study was performed among residents of Perobatang Village in Southwest Sumba district in July 2016. Eye examinations were conducted by ophthalmologists, and visual acuity was measured by optometrists. Participants were provided with appropriate treatment according to diagnosis. Surgical services were offered two months after the examination.

Results: After eximining a total of 667 of 1,459 (46\%) residents, the result showed that the most frequent ocular problems were presbyopia (30.8\%), cataract $(12.8 \%)$, refractive error $(11.3 \%)$, and pterygium (10.7\%). The proportion of myopia was $5.9 \%$, hyperopia was $5.0 \%$, and astigmatism was $2.2 \%$. Moreover, the proportion of blindness was $10 \%$. Cataract caused blindness in 44 participants. Other causes of blindness included age-related macular degeneration, retinopathy, optic atrophy, glaucoma, retinal detachment and trauma.

Conclusion: The burden of ocular problems in Perobatang Village, Southwest Sumba, Eastern Indonesia was high. These findings showed the importance of public health action from local government and non-governmental organizations to improve eye care services in Southwest Sumba district.

Keywords: blindness, Indonesia, Southwest Sumba, underdeveloped district, visual impairment pISSN: 0853-1773 • eISSN: 2252-8083 • https://doi.org/10.13181/mji.v26i4.1808 • Med J Indones. 2017;26:277-85 - Received 31 Jan 2017 - Accepted 15 Dec 2017

Corresponding author: Ratna Sitompul, ratna_sitompul@yahoo.com

Copyright @ 2017 Authors. This is an open access article distributed under the terms of the Creative Commons Attribution-NonCommercial 4.0 International License (http://creativecommons.org/licenses/by-nc/4.0/), which permits unrestricted non-commercial use, distribution, and reproduction in any medium, provided the original author and source are properly cited. 
Visual impairment and blindness are major concerns in underdeveloped regions worldwide. ${ }^{1}$ Low socio-economic status, lack of awareness, and limited access to eye care services increase the risk of blindness. ${ }^{2}$ World Health Organization (WHO) has launched the Universal Eye Health Global Action Plan 2014-2019, which aims to reduce avoidable blindness by $25 \%$ in $2020 .^{3}$ To this end, WHO promotes the assessment of magnitude and causes of visual impairment by implementing eye care services and encourages the development and implementation of integrated national eye health policies.

As Indonesia is the fourth most populous country in the world, these challenges are very relevant. The overall prevalence of blindness in the general population of Indonesia was $0.6 \%$ in $2013 .{ }^{4}$ One of the highest blindness rates has been reported in the province of Nusa Tenggara Timur (NTT), at 1\% for blindness and 1.6\% for low vision. ${ }^{4}$ However, due to the vast coverage area and difficult access to remote areas, eye care programs have not been able to reach all areas, including Southwest Sumba district.

Prevalence estimates of ocular diseases in a given district are important to plan the programs of eye care services. Field surveys are required in each district because they may differ substantially in ethnicity, geography, lifestyle, and environmental exposure, making each district unique. Until now, no field survey has been conducted in Southwest Sumba, and the only available data are from the report of the district hospital. The report showed that from 1,363 patients, cataract was the most frequently diagnosed (30.6\%), followed by presbyopia (15.6\%), myopia (9\%), conjunctivitis (6.7\%), pterygium (4.3\%), and glaucoma $(2.6 \%){ }^{5}$ The eye examinations and treatment, however, were performed by trained nurses rather than an ophthalmologist.

Based on the challenges above, we aimed to perform a field survey in Southwest Sumba District to estimate the local burden of ocular diseases. Such baseline information was envisaged to help shape programmatic planning of eye care services in the area. Perobatang Village was selected because of its impoverished condition, lack of access to health care, lack of clean water, and low hygienic practices. Thus, it represents the most underdeveloped districts in Indonesia.

\section{METHODS}

\section{Study area}

Perobatang Village is a small rural community located $70 \mathrm{~km}$ from the capital of South West Sumba district, Tambolaka. It has an area of 4,360 hectares with 315 families and a total population of 1,459 people, with the following age distribution: 498 people of 0-18 years, 231 people of 19-39 years, and 630 people of $>40$ years. The predominant occupations are fishermen and farmers.

There is no primary health care (PHC) facility in the community, and the nearest PHC is located about $3 \mathrm{~km}$ away in Bondokodi subdistrict. The nearest public eye care facility is in Karitas Hospital located in Tambolaka. Access to clean water is limited to public mono-pumps. Open defecation is still practiced in the bush, and only a few households have latrines, thus the prevalence of helminthiases is high. Study conducted in 2016 showed the prevalence of soil transmitted helminthiases was $76 \%$, consisting of $A$. lumbricoides (60\%), T. trichiura (64\%), and hookworm (10\%). ${ }^{6}$ Such conditions reflect the poor sanitation and hygiene of Perobatang residents.

\section{Data Collection}

The cross-sectional survey among village residents was conducted in July 2016 at the village chief's house, which was transformed into a makeshift clinic. The study population included all village residents, who were actively approached to undergo the eye examination by the village chief. All residents with or without ophthalmic complaints were asked to participate in the study.

The medical team consisted of five ophthalmologists, two optometrists, three ophthalmology residents, and four medical students from Faculty of Medicine, Universitas Indonesia. After oral inform consent was obtained, medical history was taken, followed by eye examinations. Visual acuity was examined using an auto-refraction machine and Snellen chart. Vision of $6 / 60$ was assessed by counting fingers at less than six meters; if failed a flashlight was used to assess light perception.

Visual acuity was classified as normal $(\geq 6 / 18)$, low $(<6 / 18-3 / 60)$, and blindness $(<3 / 60)$. 
Children who were unable to read or pointed out directions were examined with the fix and follow test. Improvements of vision after a pinhole test were categorized as refractive errors and given a prescription for corrective lenses, provided two months after the examination.

An anterior segment evaluation was done using a hand slit-lamp, and funduscopy was performed if indicated, with pupils being dilated using tropicamide $1 \%$ eye drops. A posterior segment assessment was carried out using a direct ophthalmoscope, and intraocular pressure was measured using Schiotz tonometer.

Diagnosis was conducted by ophthalmologists, and subjects were treated based on their diagnosis in accordance with clinical standards. Eye infections were treated with antibiotics and dry eye were treated with artificial tear drops. Refractive errors were corrected with spectacles, and patients with cataract, pterygium and glaucoma were scheduled for surgeries in Karitas Hospital two months after the examination. The surgery was carried out using the phacoemulsification technique or extra-capsular cataract extraction for patients with hard cataracts or weak epithelial tissue in the cornea. Ethical approval was obtained from the ethical committee of Faculty of Medicine, Universitas Indonesia (clearance number 877/ UN2.F1/ETIK/2016 protocol number 16281).

\section{RESULTS}

\section{Demographic characteristics of the subjects}

From 1,459 residents of Perobatang, 667 people voluntarily enrolled to get eye examination (46\%). Table 1 showed that most of the subjects were $<40$ years $(56.8 \%)$, women $(58.8 \%)$ and primary school graduates (37.9\%). The age ranged from 4 months to 80 years. Occupations included students (27.6), fishermen (25.5), farmers (19.9\%), housewives (21.7\%) and others $(5.3 \%)$.

\section{The proportion of ocular problems}

The number of subjects for one ocular disease was the total subjects having ocular disease in left eye, right eye or both eyes as shown in Table 2. One subject may have more than one ocular disease. The most frequently observed ocular problems were presbyopia $(30.8 \%)$, cataract $(12.8 \%)$,
Table 1. The demographic characteristics of Subjects in Perobatang Village, 2016

\begin{tabular}{lcc|}
\hline Characteristics & $\begin{array}{c}\text { Total } \\
\mathrm{n}(\%)\end{array}$ & $95 \% \mathrm{CI}$ \\
\hline $\begin{array}{l}\text { Gender } \\
\quad \text { Male }\end{array}$ & $275(41.2)$ & $37.5-44.9$ \\
\hline Female & $392(58.8)$ & $55.1-62.5$ \\
\hline Age & & \\
\hline $0-16$ & $204(30.6)$ & $27.1-34.1$ \\
\hline $17-39$ & $175(26.2)$ & $22.9-29.5$ \\
\hline$\geq 40$ & $288(43.2)$ & $39.4-47.0$ \\
\hline Education & & \\
\hline No education & $82(12.3)$ & $9.8-14.8$ \\
\hline Primary school & $253(37.9)$ & $34.2-41.6$ \\
\hline Junior high school & $104(15.6)$ & $12.9-18.4$ \\
\hline Senior high school & $175(26.2)$ & $22.9-29.5$ \\
\hline Undergraduate & $53(8.0)$ & $5.9-10.1$ \\
\hline Occupation & & \\
\hline Students & $184(27.6)$ & $24.2-31.0$ \\
\hline Fisherman & $170(25.5)$ & $22.2-28.8$ \\
\hline Housewife & $145(21.7)$ & $18.6-24.8$ \\
\hline Farmer & $133(19.9)$ & $16.9-22.9$ \\
\hline Others & $35(5.3)$ & $3.6-7.0$ \\
\hline
\end{tabular}

refractive error (11.3\%) and pterygium (10.7\%). Former trauma cases were found in the form of corneal cicatrix $(1.1 \%)$ and traumatic cataract $(0.7 \%)$. There were 67 subjects with blindness (10\%). Degenerative diseases contributed in causing blindness to Perobatang residents, such as age-related macular degeneration, retinopathy, and optic atrophy.

Small numbers of ocular diseases were also found such as conjunctivitis, dry eye, retinopathy, amblyopia, glaucoma, subconjunctival hemorrhage, entropion, corneal cicatrix, pingueculitis, optic atrophy, retinal detachment, phthisis bulbi, adherent leukoma and uveal prolapse.

To identify the proportion of ocular problems in children (0-16 year-age group), Table 3 shows the proportion of ocular problems among 204 participants. The most common ocular problems were refractive error (2\%) and blindness (2.5\%); most blindness was due to trauma (5\%). Other ocular problems were conjunctivitis, intermittent strabismus, subconjunctival hemorrhage and optic atrophy. 
Table 2. The proportion of ocular problems among residents of Perobatang Village, 2016 (n=667)

\begin{tabular}{|c|c|c|c|c|}
\hline Diagnosis & $\begin{array}{c}\text { OD } \\
\mathrm{n}(\%)\end{array}$ & $\begin{array}{c}\text { OS } \\
\text { n (\%) }\end{array}$ & $\begin{array}{c}\text { ODS } \\
\text { n (\%) }\end{array}$ & $\begin{array}{c}\text { Subjects } \\
\mathrm{n}(\%)\end{array}$ \\
\hline \multicolumn{5}{|l|}{ Ocular Problems* } \\
\hline Presbyopia & - & - & - & $206(30.8)$ \\
\hline Cataract & $4(0.5)$ & $9(1.3)$ & $73(10.9)$ & $86(12.8)$ \\
\hline Refractive error & $6(0.8)$ & $8(1.1)$ & $62(9.2)$ & $76(11.3)$ \\
\hline Pterygium & $19(2.8)$ & $15(2.2)$ & $38(5.6)$ & $72(10.7)$ \\
\hline Pseudophakia & $6(0.8)$ & $1(0.1)$ & $1(0.1)$ & $8(1.1)$ \\
\hline Conjunctivitis & 0 & $1(0.1)$ & $3(0.4)$ & $4(0.5)$ \\
\hline Dry eye & $1(0.1)$ & $1(0.1)$ & $2(0.2)$ & $4(0.5)$ \\
\hline Aphakia & 0 & $1(0.1)$ & $2(0.2)$ & $3(0.4)$ \\
\hline Retinopathy & 0 & $1(0.1)$ & $2(0.2)$ & $3(0.4)$ \\
\hline Amblyopia & 0 & $1(0.1)$ & $1(0.1)$ & $2(0.2)$ \\
\hline Lithiasis & $1(0.1)$ & $1(0.1)$ & 0 & $2(0.2)$ \\
\hline Strabismus intermittent & 0 & 0 & $1(0.1)$ & $1(0.1)$ \\
\hline Glaucoma & 0 & $1(0.1)$ & 0 & $1(0.1)$ \\
\hline Subconjunctival hemorrhage & $1(0.1)$ & 0 & 0 & $1(0.1)$ \\
\hline Entropion & $1(0.1)$ & 0 & 0 & $1(0.1)$ \\
\hline Pingueculitis & $1(0.1)$ & 0 & 0 & $1(0.1)$ \\
\hline \multicolumn{5}{|l|}{ Blindness } \\
\hline Cataract: & $9(1.3)$ & $14(2.0)$ & $21(3.1)$ & $44(6.5)$ \\
\hline Cataract & $6(0.8)$ & $13(1.9)$ & $18(2.6)$ & $37(5.5)$ \\
\hline Cataract + refractive error & $1(0.1)$ & 0 & $2(0.2)$ & $3(0.4)$ \\
\hline Cataract + corneal cicatrix & $1(0.1)$ & 0 & 0 & $1(0.1)$ \\
\hline Cataract + AMD & $1(0.1)$ & 0 & 0 & $1(0.1)$ \\
\hline Cataract + retinopathy & 0 & 0 & $1(0.1)$ & $1(0.1)$ \\
\hline Cataract + retinal detachment & 0 & $1(0.1)$ & 0 & $1(0.1)$ \\
\hline Corneal cicatrix & $3(0.4)$ & $2(0.2)$ & $2(0.2)$ & $7(1.0)$ \\
\hline Optic atrophy & $2(0.2)$ & $1(0.1)$ & $1(0.1)$ & $4(0.5)$ \\
\hline Retinal detachment & $1(0.1)$ & $1(0.1)$ & 0 & $2(0.2)$ \\
\hline Aphakia & 0 & 0 & $2(0.2)$ & $2(0.2)$ \\
\hline Refractive error & $2(0.2)$ & $1(0.1)$ & $2(0.2)$ & $2(0.2)$ \\
\hline Amblyopia & 0 & 0 & $1(0.1)$ & $1(0.1)$ \\
\hline Phthisis bulbi & $1(0.1)$ & 0 & 0 & $1(0.1)$ \\
\hline Anophthalmia & $1(0.1)$ & 0 & 0 & $1(0.1)$ \\
\hline Nonfunctional eye & $1(0.1)$ & 0 & 0 & $1(0.1)$ \\
\hline Adherent leukoma & 0 & $1(0.1)$ & 0 & $1(0.1)$ \\
\hline Uveal prolapse & 0 & $1(0.1)$ & 0 & $1(0.1)$ \\
\hline Total blindness & & & & $67(10)$ \\
\hline
\end{tabular}

*One subject may have more than one ocular disease. $\mathrm{OD}=$ oculi dextra; $\mathrm{OS}=$ oculi sinistra, $\mathrm{ODS}=$ oculi dextra et sinistra; $\mathrm{AMD}=$ agerelated macular degeneration

\section{Refractive Error}

The proportion of myopia was $5.9 \%$, hyperopia $5.0 \%$ and astigmatism was $2.2 \%$ (Table 4 ). There were two subjects with myopia and one subject with hyperopia who had high difference of refractive power (more than 2.5 dioptri between both eyes).

As shown in Table 5, myopia and hyperopia were mostly seen in subjects $>40$ years old, primary 
Table 3. Proportion of ocular problems among children 0-16 years old, Perobatang Village, 2016 ( $n=204$ )

\begin{tabular}{lcccc}
\hline \multicolumn{1}{c}{ Diagnosis } & $\begin{array}{c}\text { OD } \\
\mathrm{n}(\%)\end{array}$ & $\begin{array}{c}\text { OS } \\
\mathrm{n}(\%)\end{array}$ & $\begin{array}{c}\text { ODS } \\
\mathrm{n}(\%)\end{array}$ & $\begin{array}{c}\text { Subjects } \\
\mathrm{n}(\%)\end{array}$ \\
\hline Ocular Problems & & & & \\
Refractive error & 0 & $1(0.4)$ & $3(1.4)$ & $4(1.9)$ \\
Conjunctivitis & 0 & $1(0.4)$ & $2(0.9)$ & $3(1.4)$ \\
Strabismus intermittent & 0 & 0 & $1(0.4)$ & $1(0.4)$ \\
Subconjunctival hemorrhage & $1(0.4)$ & 0 & 0 & $1(0.4)$ \\
Blindness & & & 0 & $1(0.4)$ \\
Corneal cicatrix (trauma) & 0 & $1(0.4)$ & 0 & $1(0.4)$ \\
Traumatic cataract & 1 & 0 & 0 & $1(0.4)$ \\
Traumatic cataract + corneal cicatrix & $1(0.4)$ & 0 & $1(0.4)$ & $1(0.4)$ \\
Optic atrophy & 0 & 0 & $1(0.4)$ \\
Uveal prolapse (trauma) & & & $5(2.5)$ \\
Total blindness & 0 & $1(0.4)$ & 0 & \\
\hline
\end{tabular}

Table 4. Proportion of refractive error among residents in Perobatang Village, 2016

\begin{tabular}{lccccc}
\hline Refractive error & $\begin{array}{c}\text { OD } \\
\mathrm{n}(\%)\end{array}$ & $\begin{array}{c}\text { OS } \\
\mathrm{n}(\%)\end{array}$ & $\begin{array}{c}\text { ODS } \\
\mathrm{n}(\%)\end{array}$ & $\begin{array}{c}\text { Subjects } \\
\mathrm{n}(\%)\end{array}$ & $\Delta 2.5 \mathrm{D}$ \\
\hline Myopia & $4(0.5)$ & $8(1.1)$ & $28(4.1)$ & $40(5.9)$ & $2(0.2)^{*}$ \\
Hyperopia & $3(0.4)$ & $2(0.2)$ & $29(4.3)$ & $34(5.0)$ & $1(0.1) \dagger$ \\
Astigmatism & $3(0.4)$ & $3(0.4)$ & $9(1.3)$ & $15(2.2)$ & - \\
\multicolumn{1}{c}{ Simple astigmatism } & 0 & $1(0.1)$ & $1(0.1)$ & $2(0.2)$ & - \\
\multicolumn{1}{c}{ Astimagtism + myopia } & 0 & 0 & $5(0.7)$ & $9(1.3)$ & - \\
Astimagtism + hyperopia & 0 & $1(0.1)$ & $3(0.4)$ & $4(0.5)$ & - \\
\hline
\end{tabular}

*female 26 years old, female 59 years old. `female 69 years old.One subject may have more than one type of refractive error

school graduates, and farmers. Hyperopia was more common in female (3.2\%) than myopia (2.9\%).

\section{The proportion of cataract}

Cataract was diagnosed in 93 subjects (13.1\%) (Table 6). Cataract caused blindness in 44 $(47.3 \%)$ subjects, $21(47.7 \%)$ of which suffered from bilateral blindness. There were 33 (35.5\%) subjects who had cataract surgery indications and scheduled for surgery within two months after the examination.

\section{DISCUSSION}

The goal of the 2014-2019 Universal Eye Health Global Action Plan, which was encouraged by WHO, is to reduce avoidable blindness by $25 \%$ in 2019. This is essential to plan further eye care services and problem-solving measures by nations worldwide. WHO expects active participation from the government and other stakeholders to implement national policies and plans to eliminate blindness. National policy is expected to be carried out nation-wide from primary care level to referral centers. These steps have been taken by nations worldwide, including Indonesia. However, Indonesia experiences difficulties due to its challenging geographical access and vast area coverage leaving rural, remote, and underdeveloped districts unattended.

As an initial step, collection of data regarding pattern and prevalence of ocular diseases is essential especially in rural and underdeveloped areas. Perobatang Village is an excellent example as it highly requires medical assistance. This study showed that the most common ocular problems at Perobatang Village, Southwest Sumba 
Table 5. Proportion of refractive error based on demographic characteristics of the subjects

\begin{tabular}{|c|c|c|c|c|c|c|}
\hline Characteristics & $\begin{array}{l}\text { Myopia } \\
\text { n (\%) }\end{array}$ & $\begin{array}{c}\text { Myopia + ast } \\
\text { n (\%) }\end{array}$ & $\begin{array}{c}\text { Hyperopia } \\
\text { n (\%) }\end{array}$ & $\begin{array}{c}\text { Hyperopia + ast } \\
\text { n (\%) }\end{array}$ & $\begin{array}{l}\text { All ast } \\
\mathrm{n}(\%)\end{array}$ & $\begin{array}{c}\text { Simple ast } \\
\mathrm{n}(\%)\end{array}$ \\
\hline \multicolumn{7}{|l|}{ Age } \\
\hline $0-16$ & $2(0.2)$ & 0 & $1(0.1)$ & 0 & $1(0.1)$ & $1(0.1)$ \\
\hline $17-39$ & $13(1.9)$ & $3(0.4)$ & $1(0.1)$ & $1(0.1)$ & $4(0.5)$ & 0 \\
\hline$\geq 40$ & $25(3.7)$ & $6(0.8)$ & $32(4.7)$ & $3(0.4)$ & $10(1.4)$ & $1(0.1)$ \\
\hline \multicolumn{7}{|l|}{ Gende } \\
\hline Male & $20(2.9)$ & $5(0.7)$ & $12(1.7)$ & $1(0.1)$ & $7(1.0)$ & $1(0.1)$ \\
\hline Female & $20(2.9)$ & $4(0.5)$ & $22(3.2)$ & $3(0.4)$ & $8(1.1)$ & $1(0.1)$ \\
\hline \multicolumn{7}{|l|}{ Education } \\
\hline No education & $2(0.2)$ & $1(0.1)$ & 0 & 0 & $1(0.1)$ & 0 \\
\hline Primary school & $14(2.0)$ & $3(0.4)$ & $15(2.2)$ & $3(0.4)$ & $7(1.0)$ & $1(0.1)$ \\
\hline Junior high school & $5(0.7)$ & $2(0.2)$ & $2(0.2)$ & $1(0.1)$ & $3(0.4)$ & 0 \\
\hline Senior high school & $13(1.9)$ & 0 & $16(2.3)$ & 0 & $1(0.1)$ & $1(0.1)$ \\
\hline Undergraduate & $6(0.8)$ & $3(0.4)$ & $1(0.1)$ & 0 & $3(0.4)$ & 0 \\
\hline \multicolumn{7}{|l|}{ Occupation } \\
\hline Fisherman & $6(0.8)$ & $1(0.1)$ & $5(0.7)$ & $1(0.1)$ & $2(0.2)$ & 0 \\
\hline Farmer & $15(2.2)$ & $3(0.4)$ & $9(1.3)$ & $1(0.1)$ & $4(0.5)$ & 0 \\
\hline Other & $19(2.8)$ & $5(0.7)$ & $20(2.9)$ & $2(0.2)$ & $9(1.3)$ & $2(0.2)$ \\
\hline
\end{tabular}

Ast= astigmatism

Table 6. Proportion of cataract among residents in Perobatang Village, 2016

\begin{tabular}{lcccc}
\hline \multicolumn{1}{c}{ Type } & $\begin{array}{c}\text { OD } \\
\mathrm{n}(\%)\end{array}$ & $\begin{array}{c}\text { OS } \\
\mathrm{n}(\%)\end{array}$ & $\begin{array}{c}\text { ODS } \\
\mathrm{n}(\%)\end{array}$ & $\begin{array}{c}\text { Subjects } \\
\mathrm{n}(\%)\end{array}$ \\
\hline Immature & $6(0.8)$ & $6(0.8)$ & $60(8.9)$ & $72(10.7)$ \\
Mature & $2(0.2)$ & $6(0.8)$ & $6(0.8)$ & $14(2.0)$ \\
Hypermature & $1(0.1)$ & 0 & 0 & $1(0.1)$ \\
Traumatic & $2(0.2)$ & $3(0.4)$ & 0 & $5(0.7)$ \\
Complicated & 0 & $1(0.1)$ & 0 & $1(0.1)$ \\
\hline
\end{tabular}

$\mathrm{OD}=$ ocular dextra; OS= ocular sinistra; ODS= ocular dextra and sinistra

were presbyopia, refractive error, cataract, and pterygium. Blindness and visual impairment in the districts were high as they were lack of health facilities especially eye care services. These districts also suffered from poverty and low education, enhancing the magnitude of the problem.

Presbyopia is an age-related eye disorder caused by progressive loss of accommodative amplitude that is still a major concern in developing countries. Man et $\mathrm{al}^{7}$ reported high (33.9\%) prevalence of uncorrected presbyopia in a multiethnic Asian population. Nearly all patients with presbyopia did not possess spectacles, and those subjects had difficulties in daily activities. ${ }^{8}$ Study in East Africa found that only 18\% of 340 patients suffering from presbyopia had spectacles because they could not afford spectacles, the insubstantial need of spectacles, and the lack of access. ${ }^{9,10}$ Nirmalan et al ${ }^{11}$ reported the noticeable difficulties in activities requiring near-vision; patients complaint of difficulties in recognizing small objects and "unable to manage any near world". This study found high proportion of presbyopia (30.8\%). This condition was worsened by lacking of corrective glasses which led to difficulties in weaving traditional fabrics as one of their primary sources of income. In addition, they also had difficulties in reading small letters such as those in Qur'an, Bible, or newspapers. ${ }^{12}$

Refractive error is the most common etiology of visual impairment due to failure of precisely focusing rays of light from an object on to the retinal layer resulting in blurred vision and requiring a refractive correction in order to see clearly. ${ }^{11-12}$ In this study, there were 76 participants $(11.3 \%)$ with refractive errors, four of them were in 0-16 year age group. This condition required refractive 
correction as it caused moderate to severe visual impairment. In addition, there were two subjects with myopia and one subject with hyperopia who had high difference of refractive power (more than 2.5 dioptri between both eyes). Difference of more than 2.5 dioptri between two eyes require contact lens or refractive surgery, in which both are inaccessible to these participants. In this study, myopia was more common in male; however, most studies showed no association between gender and hyperopia. ${ }^{14}$ Most people with refractive error were farmers and fishermen. Outdoor activity has been associated with refractive error development. People with limited outdoor time and high usage of eye accommodation (i.e tailor and waiver) tend to be myopic; on the other hand, those with high levels of outdoor activity had the most hyperopic mean refraction. ${ }^{15}$

Uncorrected refractive error was the leading cause of moderate to severe visual impairment. Hence, it requires appropriate refractive correction, using spectacles, contact lenses, or refractive surgery. Spectacles are mostly used as treatment of corrective error in developing countries because of its simplicity and affordable cost. Residents of Perobatang Village who had their eyes examined and were diagnosed with refractive error, had not used spectacles. Most of them could not afford spectacles, thus we provided spectacles two months after examination. The two subjects with myopia and one subject with hyperopia who had high difference of refractive power require referral to cities with eye care centers to receive corrective contact lenses or refractive surgery.

Cataract is defined as lens opacification with blurred vision and experiencing glare or haloes from lights as the symptoms. ${ }^{16}$ Although aging is the most well-known risk factor for cataract development, there are other individual factors such as socioeconomic status, gender, certain racial or ethnic groups, and genetic factor. Lifestyle could affect cataract development, which are ultraviolet-B exposure, cigarette smoking, and alcohol consumption. Other factors in cataract formation are diet, systemic diseases, and ocular disorder. ${ }^{17}$ People living in Perobatang Village mostly work as fishermen or farmers. They spend most of their working hours outdoor without sun-glasses or other protective measures, hence they are heavily exposed to sunlight. The proportion of cataract in our study was $16.1 \%$, while Indonesian National Health Survey in 2013 showed that the cataract prevalence was $1.8 \%$, with the highest prevalence in North Celebes $(3.7 \%)$ and the lowest was in Jakarta $(0.9 \%) .{ }^{4}$ The National Survey also showed that most cataract patients were not aware of the presence of cataract $(51.8 \%)$ and were reluctant to undergo surgery due to financial problems $(11.6 \%)$, fear of surgery $(8.1 \%)$, and belief that cataract was a normal aging process. ${ }^{4,17}$ Most of cataract patients in Perobatang Village were not reluctant to undergo surgery, however due to lack of funding for transportation and hospital fee, they could not undergo surgery and in hope to the social service for cataract operation. In our study, there were 44 participants suffering from blindness due to cataract, 21 of them had bilateral blindness; such cases must be prioritized for surgery. If one of the vision is corrected through the surgery, the patient could have a normal life.

Pterygium is a fibrovascular proliferative disease of bulbar conjunctiva towards cornea with irritation, visual disturbances, cosmetic issues as symptoms, and highly associated to ultraviolet (UV) exposure. ${ }^{18,19}$ In Perobatang Village, the proportion of pterygium was $10.7 \%$ while the Indonesian Health Survey in 2013 showed the prevalence of pterygium was $8.3 \%$ with the highest was in Bali (25.2\%) and the lowest was in Banten (3.9\%). ${ }^{4}$ The prevalence of pterygium was higher in lower latitudes, which has higher sunlight exposure. ${ }^{20}$ Another risk factor was the cumulative time spent doing outdoor activities. Public education to encourage the use of appropriate protective measures for outdoor workers is very important. It is recommended to wear sunglasses and hats to minimize exposure to UV and strong wind.

This study provides a glimpse of the public health challenges that are faced by developing countries. There are many underdeveloped regions with undiagnosed ocular diseases requiring specific programs and support from the government through their policies. The absence of eye care services in this underdeveloped community contribute to the high prevalence of blindness and visual impairment. Eye disorders are not detected and managed in a timely manner, allowing them to deteriorate and eventually progress to blindness. The only hospital in the district does not offer any eye care services by ophthalmologists. Given the 
long distance, logistics, and costs, only few of the villagers could afford to seek eye care services located in other islands.

Currently, there are only six ophthalmologists in NTT Province serving one vast province with many islands which are difficult to access. Thus, the allocation of the regional budget expenditure to recruit more ophthalmologists is required. These visitations must be supported by government, nongovernmental organizations (NGOs), universities, professional organizations, and other stakeholders in terms of mobile facilities, other logistics, and financing to be sustainable. The event must take place locally and easy to access as people who live in rural area tend to be reluctant to seek health facilities and would rather to be treated in their residents. Other solution is working together with nearby medical schools to send their chief ophthalmology residents to remote areas as part of their training program.

Furthermore, local government must participate actively by announcing the schedule of the event to people and organizing it. ${ }^{21}$ This, in hope with improvement of local health facilities, will go a long way in improving vision of people in underdeveloped regions and their quality of life. This must be carried out not only in Southwest Sumba, but also in other underdeveloped districts where shortage of manpower and facilities exist. Southwest Sumba district is one of the magnets of tourism in the eastern part of Indonesia. The tourism industry in this region could help in term of giving back to the people by conducting a mass social service in eye care program as part of the community social responsibility programs.

The limitation of this study was the cross sectional study with no follow up data. However, this study serves as an important reminder for government officials to start prioritizing programs to bring eye care to remote areas as suggested by WHO by reallocating their funds and channel their concerns. This survey serves as an example not only to the Indonesian government, but also to other developing nations with challenging geographical terrains and unequal distribution of resources. This survey highlights the importance of eye care in remote underdeveloped areas and urges the government to support periodic annual visitations by ophthalmologists to conduct eye examinations and surgeries.
In conclusion, the burden of ocular problems in Perobatang Village, Southwest Sumba, Eastern Indonesia was high. The variety of ocular problems such as presbyopia, refractive error, cataract, and pterygium could be a based on priority for government program in Southwest Sumba district.

\section{Conflicts of Interest}

Saleha Sungkar is one of the editorial board members, but was not involved in the review or decision process of the article.

\section{Acknowledgment}

Authors would like to thank the chief of the village, the head of the district health office, and the head of the Southwest Sumba district, for their support during the study. Authors would also like to thank Raph L. Hamers MD PhD from Eijkman Oxford Clinical Research Unit (EOCRU) and Indonesia Oxford Clinical Research Laboratory (IOCRL) for his valuable inputs in the language aspect of this manuscript.

\section{REFERENCES}

1. Resnikoff S, Pascolini D, Etya'ale D, Kocur I, Pararajasegaram R, Pokharel GP, et al. Global data on visual impairment in the year 2002. Bull World Health Organ. 2004;82(11):844-51.

2. Jaggernath J, Overland L, Ramson P, Kovai V, Chan VF, Naidoo KS. Poverty and eye health. Health. 2014;6:184969.

3. WHO. Universal eye health: a global action plan 20142019. Spain: WHO; 2013.

4. Indonesian Ministry of Health. Indonesian health profile 2013. Jakarta: Kementerian Kesehatan Republik Indonesia; 2013. Indonesian.

5. Sitompul S. Retrospective hospital-based analysis of disease of the eye at a rural and impoverished district in Eastern Indonesia in 2015. Forthcoming.

6. Taufik MIS. Evaluation of Soil Transmitted Helminths Eradication Using Triple Dose Albendazole in Perobatang Village, Southwest Sumba, Indonesia [thesis]. Jakarta: Universitas Indonesia; 2017. Indonesian.

7. Kidd Man RE, Fenwick EK, Sabanayagam C, Li LJ, Gupta P, Tham YC, et al. Prevalence, correlated, and impacts of uncorrected presbyopia in a multiethnic asian population. Am J Ophthalmol. 2016;168:191-200.

8. Patel I, Munoz B, Burke AG, Kayongoya A, McHiwa W, Schwarzwalder AW, West SK. Impact of presbyopia on quality of life in a rural African setting. Ophthalmology. 2006;113:728-34.

9. Laviers HR, Omar F, Jecha H, Kassim G, Gilbert C. Presbyopic spectacle coverage, willingness to pay for near correction and the impact of correcting uncorrected presbyopia in adults in Zanzibar, East Africa. Invest Ophthalmol Vis Asci. 2010;51:1234-41. 
10. Marmamula S, Keefe JE, Rao GN. Population-based cross-sectional study of barriers to utilization of refraction services in South India. BMJ Open. 2011;1(1):e000172.

11. Nirmalan PK, Krishnaiah S, Shamanna BR, Rao GN, Thomas R. A population based assessment of presbyopia in the state of Andhra Pradesh, South India: the Andhra Pradesh Eye Disease Study. Invest Ophthalmol Vis Sci. 2006;47:2324-8.

12. Williams KM, Verhoeven VJM, Cumberland P, Bertelsen G, Wolfram C, Buitendijk GH, et al. Prevalence of refractive error in Europe: the Euro Epidemiology Consortium. Eur J Epidemiol. 2015;30:305-15

13. Wong TY, Zheng Y, Jonas JB, Flaxman SR, Keeffe, Leasher J, et al. Prevalence and causes of vision loss in East Asia: 1990-2010. Br J Ophtalmol. 2014;98:599-604.

14. Pan SW, Zheng YF, Anuar AR, Chew M, Gazzard G, Aung $\mathrm{T}$, et al. Prevalence of refractive errors in a multiethnic asian population: the Singaporean epidemiology of eye disease study. Invest Opthalmol Vis Sci. 2013;54:2590-8.
15. Pan CW, Ramamurthy D, Saw SM. Worldwide prevalence and risk factors for myopia. Opthalmic Physiol Opt. 2012;32:3-16.

16. Liu YC, Wilkins M, Kim T, Malyugin B, Mehta JS. Cataract. Lancet. 2017;390:600-12.

17. World Health Organization. Global data on visual impairments 2010. Sweden:WHO;2012.

18. Liu L, Wu J, Geng J, Yan Z, Huang D. Geograhical prevalence and risk factor for pterygium: a systematic review and meta-analysis. BMJ Open. 2013;3:e003787.

19. Zoroquiain P, Jabbour S, Aldrees S, Villa N, BravoFilho V, Dietrich H, et al. High frequency of squamous intraepithelial neoplasia in pterygium related to low ultraviolet light exposure. Saudi Journal of Ophthalmology. 2016;30:113-6.

20. Cao XG, Li XX, Bao YZ. Relationship between pterygium and age-related cataract among rural populations living in two different latitude areas in China. Int J Clin Exp Med. 2017;10(2):3494-501.

21. Strausser R. Rural health around the world: challenges and soutions. Family Practice. 2003;20:457-63. 